\title{
ŠPECIFIKÁ FLORENSKÉHO PERSONALIZMU (SYMBOL AKO JEDINEČNÝ VZŤAH JAZYKA A OSOBY V SLOVANSKOM MYSLENÍ) ${ }^{1}$
}

\author{
Specific Features of Florenski's Personalism \\ (The Concept of the Symbol as a Unique Relationship of Language \\ and Personal Being in Slavic Thought)
}

\author{
Peter Rusnák
}

DOI: 10.17846/CL.2018.11.2.168-178

\begin{abstract}
RUSNÁK, Peter: Specific Features of Florenski's Personalism (The Concept of the Symbol as a Unique Relationship of Language and Personal Being in Slavic Thought). Florenski's philosophy examines the notion of truth and, at the same time, the thought of a personal being and transcendence in the context of original themes of Slavic thought. The Christian concept of the person significantly enriches the noetic understanding of truth by the means of the interpersonal relationship characteristic for the context of Slavic cultures. Florenski understands truth as an existential relationship with a deeper meaning, actualized in a dialogue with a personal God. The main tendencies of the Russian personalist philosophy are the presence of verticality in relation to the horizontal relationship (relationship of one person to another) and the effort to link transcendence with factuality on the basis of which Florenski establishes his concept of a personal being. Only very intense love can overcome the contradictions in human life. There is no unity, no freedom and no truth outside love. Genuine understanding of Truth can take place only in love and it is further conceivable in love only. Basic characteristics of human being (freedom, love) cannot be categorised by means of rational thinking. Human being cannot be defined in terms of reasoning. Man can only be understood by means of intuition and by means of revelation through the symbol.
\end{abstract}

Keywords: Russian philosophy, symbolic thinking, philosophy of language, personal being, truth, Trinitarian God, Slavic culture

\begin{abstract}
Abstrakt: RUSNÁK, Peter: Špecifiká Florenského personalizmu (Symbol ako jedinečný vztah jazyka a osoby v slovanskom myslení). Pre filozofické myslenie Pavla A. Florenského je príznačné, že pojem pravdy aktualizuje zároveň s myslením osoby a transcendencie v kontexte originálnych tém slovanského myslenia. Krestanský pojem osoby, jej vztahovanie sa na transcendenciu, významne obohacuje noetické uchopenie pravdy skrze interpersonálny vztahah ako je to typické $\mathrm{v}$ prostredí slovanských kultúr. Myslením transcendencie sa zároveň ruská krestanská filozofia usiluje rešpektovat a zachovávat heterogenitu, ktorá je prítomná v každej intersubjektivite. Florenského filozofia rozumie pravde na spôsob existenciálneho vztahu, ktorý sa realizuje aj na hlbšej úrovni: v dialógu s osobným Bohom. Prítomnosṫ vertikality, ktorá vstupuje do horizontálneho vztahovania sa osoby na Druhého, spolu s pokusom o spojenie transcendencie s konkrétnostou, to sú najvlastnejšie zámery ruskej personalis-
\end{abstract}

Štúdia je výstupom z grantovej úlohy VEGA č. 1/0715/16 Dostojevskij a Nietzsche v kontextoch česko-slovenskej a ruskej filozofie 19. a 20. storočia a VEGA č. 1/0231/18 Dráma ludskej slobody v ruskom filozofickom myslení 20. storočia. 
tickej filozofie, na ktorej pozadí formuluje P. A. Florenskij svoju koncepciu chápania osoby. Rozpornost prítomnú v ludskom živote je možné prekonat jedine mocou lásky. Osoba, ktorá takto zakúša svoj život prostredníctvom života Druhého, získava existenciálne poznanie, ktoré je neoddelitelné od skutočnosti. Mimo lásky však nie je možné poznat jednotu, slobodu a ani pravdu. Autentické poznanie Pravdy sa uskutočňuje v láske a len v láske je dalej myslitelné. Základné atribúty osoby (sloboda, láska) sa nedajú zachytit v racionálnych kategóriách. Ludská osoba sa vymyká každej rozumovej definícii. Osobu môžeme postihnút len $\mathrm{v}$ jednote $\mathrm{s}$ tajomstvom Krista, a to intuitívnym nahliadnutím a zjavením, ktoré však pristupujú k poznaniu osoby cez symbol.

Klúčové slová: ruská filozofia, symbolické myslenie, filozofia jazyka, osoba, pravda, Trojica, slovanská kultúra

Filozofia dialógu spolu s myslením osoby je jednou z tém filozofických úvah tzv. strieborného veku. Samozrejme v kontexte špecifík ruského myslenia, akými sú reflexia tém sobornosti, sofie a istiny, ale aj teórie symbolu. Ako správne upozorňuje Soňa Pašteková (2012, 83), pojem strieborného veku „V západnej literárnej vede korešponduje s inými zaužívanými termínmi ako fin-de-siècle, secesia, belle époque a pod. Je akýmsi poetickejším synonymom pre obdobie modernizmu v ruskej literatúre, časovo aj esteticky s ním v podstate splývajúcim. “Je to obdobie, ktoré integruje prvky moderny i avantgardy. Ak toto konštatovanie o prieniku tradičného a moderného v ruskej filozofii strieborného veku platí pre viacerých predstavitel'ov ruskej religióznej renesancie, pre filozofické a teologické dielo Florenského to platí o to viac (Obolevitch 2014, 113). V našom texte sa pokúsime poukázat' na špecifiká chápania významu osoby v myslení Pavla Alexandroviča Florenského, a to v kontexte rozvoja ruského avantgardného myslenia, špecificky v kontexte symbolizmu. To, čo vždy zostalo ambíciou P. A. Florenského, teda poznávat pravdu v živote a skrze ňu hladat cestu k Bohu, môžeme pochopit ako základný odkaz jeho filozofického diela, ktorý sa naplňa aj vo filozofickom dialógu s vedou a aj s umením. Touto štúdiou chceme predstavit menej známe Florenského filozofické úvahy, v ktorých sa zaoberal filozofiou jazyka a jej možnostami pri odkrývaní špecifík porozumenia fenoménu pravdy, a to tak, ako sa mu sprístupnil v prostredí ruskej kultúry a náboženskej tradície Východného krestanstva (Rusnák 2015, 168).

\section{Vplyv ruského symbolizmu na Florenského chápanie jazyka a osoby}

Súčasný znalec Florenského filozofickej tvorby Sergej Choružij zdôrazňuje, že „Florenskij sa, spoločne s Vjačeslavom Ivanovom a Andrejom Belým, jednoznačne zaradili do filozofického krídla ruského symbolizmu“ (Choružij 1994, 100), a preto je dôležité jeho tvorbu hodnotit v súvislosti s dobou a na pozadí jej inšpiračných zdrojov.

Symbolická tvorba literárnej, výtvarnej a hudobnej moderny nesmerovala programovo k jasnej formulácii ideí, nešlo jej o pozitivizmus exaktného vyjadrenia postojov, ale práve naopak: kládla si za ciel' prebudit’ v samotnom recipientovi artefaktu (čitatelovi alebo poslucháčovi) tvorivé možnosti porozumenia, precítenia a interpretácie. Ambíciou symbolizmu bolo pomocou vizuálnej pamäte, emocionálnych obrazov, zámerne expresívne spojených slov, farieb a tónov vytvorit možnost̉ objavit’ ideu tak, akoby sa sama práve zrodila $\mathrm{v}$ nás.

V. I. Ivanov lokalizoval v literárnom a filozofickom symbolizme dve kontradiktické pozície, ktoré sa neskôr ukázali byt významným tvorivým potenciálom celého symbolizmu: jednak modernistickú ambíciu symbolického vyjadrenia skutočnosti (Ivanov hovorí o realistickom symbolizme, ktorý tenduje k realizmu intuitívne nahliadnutelnej vyššej, transcendentnej oblasti umeleckej tvorby a ludského poznania) a potom tendencie dekadentného chápania sveta $\mathrm{v}$ umení a filozofii 
(subjektivistický symbolizmus, ktorý uznáva len imanenciu predmetného, empirického sveta). Napätie medzi týmito dvomi formami symbolizmu neskôr spôsobilo úpadok a zánik symbolistickej školy, hoci - podla Ivanova - potenciál tohto typu myslenia a chápania sveta je nesmrtelným a ešte len čaká na svoju renesanciu. Ivanov v tejto súvislosti rád hovoril o večnom symbolizme, akomsi symbolizme perennis (Ivanov 1998, 28).

Pre realistický symbolizmus nie sú symboly len relatívne znaky ludskej tvorby a myslenia. Symboly sa zjavujú v samotnej realite na spôsob znakov, ktoré d’alej odkazujú na podstatu označovaného. $\mathrm{V}$ každodennom prežívaní prirodzeného sveta je človek konfrontovaný s množstvom symbolov, ktoré mu otvárajú a sprístupňujú poznanie vyššej reality a ktorú bezprostredne robia zjavnou.

Subjektivistický symbolizmus prirovnáva Ivanov k introspektívnej krajinomal'be. Krajina nás pozýva do nej vstúpit, pričom stopy/znaky sú len náznakmi, ktoré bude potrebné domysliet. Itinerár má v rukách každý divák, ale obraz neponúka viac než len sám seba. Od samého počiatku symbolizmu bol vyzdvihovaný práve tento význam intenzifikácie pocitov. Skrytým zámerom symbolizmu sa stalo naznačenie a zamlčovanie ako technika zámerného atakovania recipientovej fantázie a myslenia. Formálny estetizmus v sebe niesol aj zabudnutie symbolistickej ambície o syntézu, čím predznačil neskorší úpadok symbolistického hnutia. Nekontrolovatelná, rozmarná a bujná fantázia viedla $\mathrm{k}$ vytváraniu prehnane subjektívnych obrazov. Tieto boli čoraz viac nepochopitelné a čitatelsky nesmierne náročné, čím zasa kauzálne vyvolávala reakcia publika $\mathrm{v}$ tvorcoch pocit osamelosti, nepochopenia a $\mathrm{v}$ konečnom dôsledku aj nepotrebnosti umenia. Tvorivá energia symbolizmu sa čoraz častejšie sústredila len na stále nové objavovanie čoraz výnimočnejších technológií prenosu umeleckej imaginácie, zabúdajúc na samotný zmysel obraznosti. Význam transcendentnej reality unikal pozornosti tvorcov a umelecká tvorivost' sa následne stávala samoúčelnou. Experimentátori v oblasti umeleckého senzualizmu sa začali podobat’ „rozčarovaným iluzionistom, vel'kňazom vel'kého Nihil“ (Ivanov 1998, 100). Pôvodná myšlienka nazretia duchovného v emocionálnom, myšlienka vyjadrenia duchovného prostredníctvom citov sa postupne transformovala na absolútne pohŕdanie objektívnou duchovnou realitou, čo viedlo k prázdnemu experimentovaniu a atmosfére pesimizmu. Zosilnenie subjektivistických tendencií v symbolizme na začiatku 20. storočia viedlo k ochudobneniu tvorivej energie umenia a filozofie, $\mathrm{k}$ duchovnej plytkosti a $\mathrm{v}$ konečnom dôsledku aj k rozkladu symbolizmu, ktorý si na začiatku od seba mnohé sluboval, no ktorý však nedokázal plne vyčerpat svoj tvorivý potenciál (Rusnák 2016, 198).

Myšlienky realistického symbolizmu sa však stali nosnými ideami Florenského filozofie jazyka. Ten sa, v kontrapozícii k symbolistickému subjektivizmu, nekontrolovanej, vyprázdňujúcej fantázie a neplodného pesimizmu, obrátil k tradícii sakrálneho umenia, k tradícii pravoslávnej estetiky, ktorá je tradíciou ruského „duchovného umenia“. Myšlienka pestovania duchovného umenia sa pre Florenského stala tak významnou a zásadnou, že dokonca považoval za potrebné a nevyhnutné napísat’ svojej manželke Olge zo Soloveckého tábora list (16. 9. 1935), v ktorom jej kladie na srdce potrebu praktizovat životné umenie symbolického nazerania skutočnosti ako lieku na taživý pocit zúfalstva v ruskej duši. Florenskij diagnostikuje chorobu svojej doby, ked’v liste píše, že „slovanská duša zabúda na nutnost’ symbolického prístupu k životu, čím následne podlieha márnomysel'nosti, duchovnej sklúčenosti, melanchólii a pesimizmu“ (Florenskij 1992, 420). Florenskij sa pritom odvoláva na myšlienky ruského symbolistu Andreja Belého (1880 - 1934). Belyj chápe filozofiu ako alternatívu k vede a umeniu, alternatívu, ktorá hl’adá vlastný prístup k nazretiu najvyššej, transcendentnej reality, podobne ako to robí napríklad symbolické umenie. „Vývoj filozofického myslenia stavia filozofiu do pozície závislosti od poznania prostredníctvom zjavenia, od poznania symbolického. (...) Spolu so zmenou teórie poznania sa potom mení aj vztah filozofie k umeniu. Filozofia stojí na ceste smerujúcej $\mathrm{k}$ poznaniu podstát, teda k poznaniu náboženskému. Náboženstvo je 
takým systémom postupne poznávaných a odhalovaných symbolov“ (Belyj 1994, 448). Andrej Belyj sa domnieva, že ak veda plánuje poznávat priestorovo-časové fenomény mimo ich spojenia s večnostou, ak sa usiluje spájat’ získané poznatky do jediného a logicky konzekventného celku, potom filozofický prístup k nazeraniu fenoménov reflektuje javy v spojení s duchovnou realitou, čo je možné len cez inak diskontinuitný rad obrazov, ktoré sú spojené určitým rytmom, resp. hudbou. „Ak je symbol oknom do Večnosti, potom sa nám akýkolvek systém symbolov nemôže javit nepretržitým, ako je to napríklad v systémoch dogmatizmu a kriticizmu, v ktorých je všetko spojené pomocou logického vztahu. Avšak je to len rad nespojitých obrazov, ktoré sprístupňujú rôzne stránky jediného“ (Belyj 1994, 429).

Najlepšou formou symbolického poznania potom už nie je forma vedeckého traktátu či štúdie, ale skôr umeleckou invenciou organizovaný systém aforizmov. „Aforizmus umožňuje okamžite preskúmat akýkolvek horizont, dodržujúc pritom vztahy medzi čast̉ami. Aforizmus je najlepším spôsobom kontaktu autora s čitatel'om za podmienky, že sa autor majstrovsky vyjadruje a čitatel' všetkému rozumie. Aforizmus predstavuje otvorené dvere na samostatnú cestu, na ktorej z jedného dobrého aforizmu môžeme vytažit viac perál ako z obsiahlej a komplikovanej knihy (...) Symbol je maximálne napätý aforizmus. A preto je aforizmus mostom k symbolu. (...) Symbol je ideálom aforizmu“" (Belyj 1994, 249-250).

O názorovej príbuznosti Belého symbolizmu a Florenského filozofie jazyka svedčí aj ich spoločný názor, podla ktorého obaja upozorňujú na protikladnú binaritu slova a pojmu. Každý pojem nás, podla Belého, orientuje na skúsenosti z minulosti. No každé živé slovo je obrátené k tvorbe budúceho. V každom živom kontakte sa vytvára niečo nové, nejaká nová skúsenost' či nový duchovný svet. Andrej Belyj to vyjadril jednoznačne: „Cielom kontaktu je v dotyku dvoch vnútorných svetov aktivovat svet tretí. (...) K tomu je však potrebné, aby slovo vzájomného kontaktu, slovo dorozumenia nebolo len všeobecným pojmom. Každý všeobecný pojem definuje pôsobenie minulých pojmov. Avšak cielom ludstva je vytvárat samotné objekty poznania, cielom každého živého kontaktu je smerovanie k budúcnosti. Preto vždy, ked’ sa všeobecné slová stávajú znakmi dorozumievania, navracajú kontakty ludí k tomu, čo už bolo predtým. A naopak, živá metaforická reč, ktorej rozumieme, aktivuje v našej fantázii plameň novej tvorivosti. Nová tvorba slov je vždy začiatkom nových poznaní" (Belyj 1994, 228).

Živé slovo Belyj pripodobňuje kvitnúcemu organizmu: je vždy poetické a, podobne ako poézia, aj živé slovo sa usiluje v sebe spájat pozemské s nebeským. Prozaické slovo už stráca jedinečnú zvukovú a malebnú obraznost’ poetického vyjadrenia, je však stále akoby na polceste k striktnému abstraktnému termínu, ktorým je „mŕtvy“ pojem. A. Belyj síce uznáva určitú krásu vedeckého termínu, krásu more geometrico, no je to krása anorganická, neživá, hoci logicky konzistentná. Belyj to vyjadruje snád' až príliš naturalisticky, ale jedná sa mu o striktné vyjadrenie spomínanej binarity: „Slovo - pojem je prekrásny, no mŕtvy krištál, ktorý vznikol vdaka ukončenému procesu rozkladania sa živého slova“ (Belyj 1994, 233).

Veda, ktorá pracuje pomocou jednoznačne vymedzených pojmov nepriamo, ale predsa potiera náboženskú skúsenost' človeka a deštruuje mytologickú tvorivost̉ ludstva, tvorivost̉ tak potrebnú k inej, estetickej či umeleckej tvorivosti. A tým vlastne prekáža aj vytváraniu nového života. „Nové slovo života je slovom poetickým. Ešte žijeme, ale žijeme len preto, lebo sa pridržiavame slov. Hra so slovami je znakom mladosti. Spod prachu úlomkov rozpadajúcej sa kultúry voláme a zariekame rečou, slovami. Vieme, že je to jediné dedičstvo, ktoré bude potrebné odovzdat detom“ (Belyj 1994, 243).

Ako úvod do Florenského filozofie jazyka a chápania osoby v ruskom personalizme sme si zvolili možnost’ odvolat’ sa na príbuznost' Florenského filozofie s tendenciami ruského symbolizmu. Podobne ako Belyj, aj Florenskij je presvedčený o význame jazyka pre existovanie kultúry, o význame medzigeneračného prenosu informácií a skúseností, čomu rozumie ako výzve zachovania 
kultúrneho dedičstva. Florenskij si myslí, že práve v slove a skrze slovo vychádza človek „za hranice svojej obmedzenosti a spája sa s historickou vôlou kultúry, ktorá prevyšuje individuálnu vôlu jedinca. (...) Spolu so slovom, ktoré vyslovím, vstupuje do priestoru aj moja skoncentrovaná vôla a sila mojej sústredenej pozornosti“ (Florenskij 1990, 243).

Florenskij zároveň súhlasí s A. Belým v tom, že vedecký pojem nie je schopný preniest̉ duchovnú energiu kultúry a individuálnu energiu jednotlivca s rovnakou intenzitou a v takej koncentrácii, ako to môže dokázat živé slovo. No Florenskij sa domnieva, že aj v exaktnom pojmosloví experimentálnej vedy musí byt prítomná, a teda aj zachovatel'ná prvotná energia živého slova. Úlohou filozofie je rozpoznat tento potenciál vedy a usilovat’ sa napomôct’ obmedzit', dnes by sme povedali, „postmodernú“ radost' z expanzie nových, v našom prípade exaktných termínov.

V závere kapitoly teda môžeme konštatovat', že filozofický symbolizmus P. A. Florenského bol inšpiračne kreovaný v podmienkach rozkvetu umeleckého symbolizmu ruského kultúrneho prostredia na začiatku 20. storočia. Doplňme len, že P. A. Florenskij nebol jediným ruským filozofom, ktorý sa nechal inšpirovat myšlienkami symbolizmu, hoci je dnes zrejmé, že aj úvahy iných myslitelov a umelcov (Ivanov, Blok, Brjusov, Petrovskij, Merežkovskij, Uspenskij, Evdokimov) boli tematicky vel’mi príbuzné Florenského filozofii jazyka (Rusnák 2017, 105).

\section{Význam symbolu vo Florenského filozofii osoby}

Takmer v každej Florenského filozofickej práci sa môžeme stretnút' (na rôznych úrovniach tematizácie) s problematikou symbolu. No snád’ najkoncentrovanejší záujem o význam symbolu a symbolického jazyka prejavil Florenskij v druhej časti diela Pri rozvodiach mysle z roku 1922, ktorého prvú verziu vypracoval na spôsob prednášok pre študentov Moskovskej duchovnej akadémie už v akademickom roku 1917/1918. Myslíme si, že Florenského pokračovanie práce, ktorá pojednáva o problematike jazyka, je inšpiratívne podnes.

Florenskij v tejto práci poukazuje na význam telesnosti človeka: všetky nástroje, ktoré človek vytvoril, sú akoby pokračovaním jeho tela. Mikroskop a teleskop sú pokračovaním oka, mechanizačné stroje sú akoby predľženými rukami, výbuch riadenej strely je akoby predľženou a mnohonásobne zosilenou pästou na vel'ké vzdialenosti. Pri výrobe nástrojov sa však človek stretáva s komplikáciami, ktoré oneskorujú jeho tvorivú činnost', čo však zároveň umožňuje zapojenie intelektu do procesu tvorby projektu či nástroja. Práca intelektu je určovaná predovšetkým pojmovo-koncepčným myslením, čo nakoniec ludský rozum natol'ko zbližuje s technickou činnostou, že sa stáva akoby jej organickou súčastou. Florenskij to vyjadruje tak, že „rozum je vždy potenciálnou technikou. A technika je aktuálnym rozumom. Inými slovami: obsahom rozumu musí byt niečo, čo skrze tvorbu zároveň poskytuje nástroje tvorby alebo myslenia“ (Florenskij 1992, 132).

Pretože obsahom rozumu sú podla Florenského pojmy a ich vzájomné vztahy, potom môžeme zároveň konzekventne tvrdit, že aj nástroje sú vlastne materializované pojmy, a preto môžu byt’ medzi zákonmi myslenia a technickými objavmi vztahy paralelizmu a pevných väzieb.

Ak človek orgány ludského tela nedokáže vedome kontrolovat, nedokáže ich riadit na úrovni vedomých aktov rozumu, potom technické nástroje sú projektmi vedomých funkcií rozumu par excellence. P. A. Florenskij však nezabúda podotknút, že podobne ako vedomé akty rozumu, sa na tvorbe technických nástrojov podielajú aj podvedomé motivácie a celá pudová sféra ludskej psychiky. „Vzorom výroby nástrojov sú telesné orgány, pretože i nástroje i orgány majú ten istý tvorivý počiatok, ktorým je inštinktívne a neuvedomelé telo. Teda existuje sféra ludskej činnosti, ktorá prebieha primárne, oproti sekundárnemu uvedomelému procesu, pričom prvotný projekt telesných orgánov i projekt technických nástrojov sú na úrovni podvedomia totožné a majú spoločnú bázu, ktorou je ludská duša“ (Florenskij 1992, 153). Florenskij chce poukázat na fakt, podla 
ktorého sa pri každom tvorivom procese zúčastňujú súčasne vedomie aj podvedomie človeka, rozum spolu s ludskými inštinktmi. Vo vedomí utvárané a dalej riadené technické vynálezy len rozširujú a intenzifikujú naše spojenie s okolitou prírodou, zatial čo človek a všetky jeho orgány sú od počiatku kontinuálne spojitými procesmi, ktoré prebiehajú do značnej miery na nevedomej úrovni. Spojenie človeka s prírodou je však natol'ko organické, že je vždy človeku už akosi vopred známe. Vzţah človeka k jeho prirodzenému prostrediu nie je vztahohom k neznámemu. „Ani ludská mysel', ani cit, ani vzrušenie - nič z toho by neexistovalo, keby táto realita nebola prítomná v híbke nášho ducha. V skutočnosti je vždy prítomná pred ním ako jej bezprostredný obsah, ako modus spojenia ducha s realitou" (Florenskij 1992, 172).

Uvedené filozofické názory sú vlastne gnozeologickými východiskami Florenského teórie symbolu. Symbol je, podla Florenského, takou realitou, ktorá je príbuzná inej realite, a to z pozície prúdiacej energie. Symbol sa však od neho odlišnej realite podobá len niektorými vonkajšími prejavmi. „Symbol nie je symbolom podla toho, či v sebe obsahuje, alebo neobsahuje ten ktorý špecifický znak, ale podla toho, či sa nachádza v niektorej z realít energia odlišnej reality“ (Florenskij 1992, 173). Preto môžeme o symboloch vypovedat nielen na základe podobnosti dvoch realít, ale práve na základe intuitívneho predpokladu vnútornej jednoty energií, ktoré generovali a dalej tvoria inak odlišné konkrétne veci. Florenskij argumentuje tvrdením, že človek je predsa len po celý život spojený so svojim okolím najrôznejšími druhmi energií, vdaka ktorým nadväzuje so svetom vzájomné vztahy. Florenskij preto považuje za najadekvátnejšie také poznanie objektov, ktoré pracuje na základe poznania príbuznosti analogických či identických energií, ktoré spájajú človeka s predmetnými obsahmi prirodzeného sveta. P. A. Florenskij je presvedčený, že poznanie sveta nie je možné bez hlbinného poznania seba samého. „Symbolika nie je lubovolnou hrou. Symbolika sa človeku sprístupňuje prostredníctvom ducha v híbkach jeho podstaty, v centre životných síl, odkial je k nej prístup. Základom symboliky nie je lubovôla, ale príroda utajená v podstate človeka (...) základy symbolického jazyka sú prítomné v podstate každého človeka“ (Florenskij 1992, 173).

Základom symboliky je samotná realita. Pre človeka je najvýznamnejšou vždy taká realita, ktorá vytvára príbuzenský vztah medzi ním a svetom. Aj preto sú symbolické jazyky rôznych národov velmi podobné. Hoci P. A. Florenskij súhlasí s názorom, podla ktorého aktivácia symbolického jazyka by nebola celkom dobre možná bez pôsobenia vonkajších síl, nad’alej trvá na tom, že „napriek tomu symbolický jazyk vyplýva vo svojej podstate z hlbín osoby“ (Florenskij 1992, 174).

Tak, ako človek často nezmyselne vytvára nepotrebné veci, vytvára aj nadbytočné pojmy a zbytočné koncepcie; človek neznečistuje len životné prostredie, ale aj jazyk a predstavy o svete. Florenskij je presvedčený, že vyviest’ človeka z pseudodemiurgického omylu k pôvodnej realite, priviest’ ho na cestu k sebe samému, ku skutočne uvedomelému životu, je schopný jedine symbolický jazyk, ktorý nie je možné vymysliet', ale jedine objavit. Len taký jazyk je médiom poznania skutočného zmyslu; jedine symbol má schopnost’ otvorit človeku prístup ku skutočnej realite. Florenskij v tomto kontexte píše o introspektívnej ceste nazerania symbolu, čo je možné len vtedy, „ked’ sa snažíme do hlibky pochopit symboly, ked' objavujeme seba samých, ale len ked’ sa usilujeme vniknút sami do seba, len vtedy objavujeme vo svojom vnútri symboly“ (Florenskij 1992, 175).

Symbolizujúca činnost ducha je exemplárne prítomná počas spánku, ked’ je výrazne oslabená kontrola centier vedomia ludskej mysle. Florenskij ju nachádza aj v imaginatívnej vizuálnej fantázii umelca, ktorá je taktiež schopná prekonávat' odpor kontroly zo strany vedomej vôle, čím vlastne napomáha sprístupneniu nových významov mentálnej symboliky. Ale aj v exaktnej empirickej vede, a to napriek striktným požiadavkám metodologického myslenia, sa pri pokusoch vedeckého spoločenstva vyriešit zložitý problém niekedy objavia tak štastne zvolené pojmy, ktorých intenzia napomáha k prielomu do hlbín inak analyticky deskribovanej reality. Florenskij zároveň dokladá, že práve špecifický a v mnohých kultúrach univerzálne prítomný charakter náboženského 
myslenia snád’ najexemplárnejšie vykazuje tendencie symbolického vyjadrenia reality, ktoré sú žriedlom filozofického a špecificky dialogického myslenia (Vadíková 2011, 24).

P. A. Florenskij rozlišuje symboly podla úrovne ich podobnosti. Za najvšeobecnejšie, univerzálne a kultúram najzrozumitelnejšie, považuje náboženské symboly, ktoré sprevádzajú ludstvo od jeho počiatkov. Historicky neskoršie formy prvých civilizácií pokladá Florenskij za kultúry v istom zmysle ambivalentné: hoci udržiavajú význam náboženskej skúsenosti v prežívaní prirodzeného sveta, zároveň však vytvárajú predpoklady pre násilné zavádzanie umelých foriem poznania, ktoré si kladú za ciel’ dosiahnutie neprirodzených cielov. Florenskij považuje za zvlášt’ nebezpečnú takú formu civilizácie, ktorá cielene „nepestuje súcit so všetkým živým a lásku k životu, ale naopak sa orientuje len na pragmatické výhody, ktoré potláčajú a ohrozujú samotnú prírodu, ktorá následne nedokáže napomôct’ imanentným prejavom kultúry. Taká civilizácia potom násilne vnucuje celej spoločnosti svoje pragmatické ciele“ (Florenskij 1992, 188).

Technokratická civilizácia a technické myslenie sa prirodzene usilujú stat sa nezávislými od akýchkolvek prirodzených zdrojov, usilujú sa odtrhnút od antropologicky fundovaného poznania, ktoré je ich vnútorným zdrojom, pričom tento násilný pohyb technokraticko-pragmatického myslenia nevyhnutne vedie ku kríze. Florenskij, podobne ako v tom čase aj Berdajev, je presvedčený, že jedine antropologické myslenie, personalistické myslenie, v ktorého strede vždy stojí jedinečná hodnota osoby môže byt adekvátnou odpoved’ou utilitárne zameraného prístupu k životu (Pružinec 2017, 134-135).

Florenskij sa odvoláva na renesančnú predstavu mikrokozmického človeka, ktorý je bytostne spojený s prostredím makrokozmu, a to prostredníctvom množstva energií a teurgických/telurických prúdení. Skutočne pravdivé poznanie sveta je podmienené objavením a poznaním týchto energetických väzieb. P. A. Florenskij sa domnieva, že človek nakoniec nemôže poznat nič z toho, čo by už v ňom nebolo prítomné aspoň v zárodku: „nie je možné si niečo plne privlastnit, ak je mi to vo svojej prirodzenosti cudzie. Privlastnit si niečo znamená urobit podobným aj to, čo spočiatku nebolo podobným, teda to, čo sa nám nepodobalo a čo ani nebolo poznané, t. j. čo pre nás de facto jednoducho neexistuje“ (Florenskij 1992, 184-185).

Symbolické myslenie pracuje na základe princípu príbuznosti: z rezervoáru poznatkov vyberá to, čo je osobe bytostne najbližšie, čo je pre jej duchovný život najvýznamnejšie a najdôležitejšie. A najdôležitejším je vždy poznanie duchovnej Pravdy, ktorá je súčasne základom vyššej reality, existenciálne nevyhnutným fundamentom života každej osoby. Každý človek sa poznaním Pravdy otvára v híbke svojej osoby tomu, čo ho viaže $\mathrm{k}$ životu, čo ho púta s vyššou realitou a čo mu umožňuje naplnit ludský život zmyslom. Florenskij, predstavitel’ scientistického skepticizmu, je presvedčený, že všetky vedecké teórie $\mathrm{v}$ zásade vždy prechádzajú procesom falzifikačných zmien a revolúcií, ale túžba človeka je nasmerovaná opačne: tenduje k úsiliu spojit život s niečím absolútnym a večným. Filozofická antropológia, ako disciplína zaoberajúca sa poznaním človeka a jeho prirodzeného sveta, nemôže byṫ aj nad’alej založená na parciálnych a nestabilných pravdách exaktných vied. Pravdy - pojmy prírodných vied stavajú na striktne empirickom základe, pričom sa podla Florenského menia „s každým závanom vetra a v našej dobe zvlášt rýchlo. Takéto pojmy by boli velmi chatrným základom každej filozofickej antropológie. Neporovnatelne spolahlivejšie sú v tomto zmysle napríklad základné pojmy lyriky a ešte viac neotrasitelné sú stabilné symboly náboženstva“" (Florenskij 1992, 190).

Ludské poznanie, ktoré má schopnost' byt životodárnym zdrojom organizmu, ktoré môže byt’ základnou oporou či fundamentom osoby, je poznaním symbolickým a to práve preto, lebo skutočné poznanie sveta je vždy antropomorfické. Znamená to, že také poznanie zostáva človeku neprístupné a uzamknuté, pokial je odtrhnuté od nazerania hlbín ludskej podstaty. Florenskij je v zásade presvedčený, že len „bezprostredná skúsenost’ osoby so svetom mi poskytuje jedinečnú príležitost’ pochopit permanentne prítomnú možnost' empirickej totalizácie sveta, jeho 
teleologické usporiadanie podobné usporiadaniu a organizácii môjho tela. Všetky pojmy, ktoré vypovedajú o svete, všetky abstraktné schémy, ktoré popisujú procesy prebiehajúce v prírode na základe kvantifikácie a numeriky (...) sú rozhodne antropomorfické, t. j. v konečnom dôsledku zobrazujú usporiadanie človeka, jeho vonkajšie i vnútorné procesy, ktoré zároveň symbolizujú aj vnútorné usporiadanie a vnútorné pohyby ludského ducha“ (Florenskij 1992, 187). Avšak to, čo skutočne naplňa ludský život zmyslom, tým, čo je pre človeka ontotvorné, je u Florenského vždy Pravda, náboženská či duchovná Pravda. Ako správne poukazuje na antropologicko-religiózny charakter ruskej filozofie strieborného veku Jaromír Feber (2017, 95-96): vzhladom na to, že táto duchovná Pravda má schopnost’ vyjadrit’ aj najhlbšie väzby človeka s vy̌̌šou, transcendentnou realitou, je aj ona nevyhnutne antropologická. Inak povedané, krestanská náuka o Bohu-Trojici je náukou bytostne antropologickou. A inou ani nemôže byt'.

Podnetné úvahy o význame realistického symbolizmu nachádzame vo Florenského umenovedných prácach, najexemplárnejšie však v texte Obrátená perspektíva. Florenskij, na základe analýzy rôznych foriem naturalizmu v umení, ukazuje, že každý pokus o uplatnenie pocitu ilúzie $\mathrm{v}$ umeleckej tvorbe nevyhnutne zlyháva a v konečnom dôsledku vždy narúša kontakt človeka s podstatou reality. Tvorivá imaginácia, ktorá si kladie za ciel fiktívne zobrazenie reality, zbavuje umeleckú invenciu schopnosti plnit svoje základné poslanie - uvádzat divákov/čitatelov do duchovného kontaktu s realitou a následne tento krehký duchovný kontakt rozvíjat' a upevňovat'. Podla Florenského totiž podstata zobrazenia predmetu nezáleží na kvalite samotného zobrazenia, pretože „predmet nie je kópiou veci, nevytvára dvojníka na periférii sveta, ale vždy poukazuje na samotný originál, poukazuje na spôsob symbolu. Naturalizmus, ako vonkajšia pravdivost', ako verné napodobnenie skutočnosti, a teda ako proces výroby zdvojenia vecí ani nie je potrebný a v zásade ani nie je možný“ (Florenskij 1996, 47).

Florenskij, vo svojej takmer platónskej vízii umenia, argumentuje názorom, podla ktorého sa na podporu naturalistických iniciatív v maliarstve zvyčajne odvoláva na teóriu perspektívy. Technické zvládnutie perspektívy je častým kritériom hodnotenia kvality obrazu. Florenskij nechce súhlasit s tvrdením, podla ktorého by snád’ v oblasti maliarskeho naturalizmu nevznikli skvostné artefakty, no ich originalita nespočíva v striktnom rešpektovaní pravidiel zobrazovania perspektívy. Podla Florenského je každé zobrazenie primárne „vždy symbolom. Každé zobrazenie zároveň je i nie je perspektívne. Umelecké stvárnenia reality sa navzájom nelíšia tým, že jedny sú symbolické a iné zasa naturalistické, ale práve tým, že sú symbolmi odlišných dimenzií reality, zobrazením rozdielnych pohladov na vec, rozdielnych spôsobov prežívania sveta a rozličných úrovní syntetickosti. Rozdielne spôsoby zobrazenia reality nie sú vzájomne odlišné na úrovni realistického zobrazenia, t. j. tým, ako sa zobrazovaný objekt odlišuje od svojho zobrazenia, ale ich odlišnost' je primárne založená na symbolickej úrovni“ (Florenskij 1996, 47).

Florenskij v tejto súvislosti poukazuje na fakt, že aj najdôslednejší zástancovia teórie perspektívy nakoniec vždy porušujú jej zásadné požiadavky, a to vtedy, ked’ začínajú pocitovat potrebu riešit reálne problémy umenia. Podla Florenského každý skutočný umelec je ochotný porušit pravidlá v záujme zobrazenia duchovnej perspektívy, teda nielen perspektívy realistickej a nutne iluzórnej, pričom je vedený zámerom umeleckého pôsobenia na duchovnú premenu diváka. „Úlohou výtvarného umenia nie je zdvojovat skutočnost', ale poskytovat' hlbšie chápanie jej architektoniky, materiálu a nakoniec aj zmyslu. To môže umelec dosiahnut v živom kontakte s realitou, precítením a empatiou. Dekoratívne umenie sa pokúša nahrádzat realitu jej zobrazením. Je to však vždy zdanlivá realita, ktorej zobrazenie chce byt doslovné, a teda asymbolické. Dekorácia je klamom, i ked' klamom pekným. Skutočné maliarstvo však stojí pred výzvou byt pravdou života, čo je možné len pomocou vyjadrenia symbolu" (Florenskij 1996, 17).

Z kunsthistorického hladiska je nesporne zaujímavý Florenského postreh, že teória perspektívy významne vplývala na umenie práve v obdobiach náboženského úpadku, teda vtedy, ked’ sa 
pretrhali väzby človeka s duchovnou realitou. Iluzionizmus $\mathrm{v}$ umení súvisí s nárastom sekularizácie. Podla Florenského sa umenie a celá kultúra stále viac orientujú na človeka-pozorovatela, ktorý, pozbavený duchovného spojenia s realitou, uprednostňuje prázdne pozorovanie javov a prijíma rolu pasívneho pozorovatela. Svet je mu lahostajný a všetky otázky vyriešené, akoby existoval v naprojektovanej sieti perspektívnych liniek a vedeckých schém. Myšlienka o tom, že sekularizácia je fenoménom súčasnosti dokladá aj Florenského názor na minulost: „Stredoveký človek vie, pre zachovanie jeho existencie musí žit v realite a musí ju rešpektovat'. Stredoveký človek je realista, ktorý stojí pevne na zemi, ktorý je pevne zakotvený v realite dňa, ak ho porovnáme s moderným človekom, ktorý rešpektuje len svoje túžby a plány, ktorý presadzuje svoje priania a vízie“ (Florenskij 1996, 26). Ak je totiž človek pevne zakorenený v realite a ak ešte nepretrhal mnohovrstevné väzby s realitou, potom je schopný vnímat’ svet vecí a slov ako svet symbolov, t. j. je schopný vidiet viac, než sa mu bezprostredne dáva, je schopný rozumiet’ hlbšie než doslovne. Avšak vtedy, ked’ človek stratil živú väzbu s realitou, s jej duchovnou híbkou, v dôsledku čoho sa stal „neosobným bytím“, až vtedy sa uspokojuje s akceptovaním fikcie, ilúzie reality. Až vtedy sa odvoláva na formálnu pravdepodobnost’ a konzistentnost’ inak na zmysle neparticipujúcich parciálnych faktov a informácií. Perspektívnost’ podla Florenského vyplýva zo subjektivistického pohladu na svet. „Perspektívnost' je spôsobom vyjadrenia meonizmu a impersonalizmu“ (Florenskij 1990, 344), pričom meonizmus je vlastne alternatívnym označením nihilizmu. Podla Florenského je podstatou meonizmu apersonalistické chápanie človeka, ktoré dalej korešponduje s asymbolickým vnímaním sveta. Depersonalizácia, odosobnenie a strata symbolického vztahovania sa na svet, ludí a Boha, tvorí jednu totalitu, totalitu sekularizovanej kultúry, totalitu onomoklastického vztahovania sa na realitu. U Florenského sú teda personalizmus a symbolizmus vzájomne organicky prepojené a navzájom podmienené, pričom existencia jedného nie je myslitelná bez existencie druhého (Rusnák 2017, 98-99).

Podla Florenského však k ohrozeniu osoby nedochádza len vplyvom asymbolicky fundovanej sekularizovanej kultúry, ale aj z dôvodu duchovnej vlažnosti, apatie a lahostajnosti človeka. Jedným z aspektov krízy súčasnej kultúry je vysoko rozvinutá špecializácia vied a disciplín, pri ktorej absentuje nárok hladania zmyslu, hladania pôvodnej jednoty ludského poznania a múdrosti. Florenskij je presvedčený, že na patologickú spoločnost̉ môže terapeuticky pôsobit práve symbolické myslenie a kultúra. Ved' Florenskij, podobne ako u nás napríklad Ludovít Štúr, neustále zdôrazňuje, že práve symboly sú takými živými orgánmi, ktoré majú schopnoste zjednotit roztrieštenú kultúru, a tak ju uzdravit' (Hamada 2011, 19).

Symbol je novým kontaktom s realitou. Je orgánom, prostredníctvom ktorého sa človeku sprístupňujú iné dimenzie skutočnosti. Skrze symboly sa uskutočňuje dotyk s realitou, akési pôvodné nahmatávanie Pravdy. „Symboly neustále vytvárajú mnohotvárne vztahy k životu. Symboly sú vo svojej podstate univerzálne, lebo - hoci majú svoj pôvod v človeku - objektívne existujú ako prostriedky porozumenia prístupné celému ludstvu. Ich univerzalita zároveň poukazuje na prítomnost’ zárodku večnosti v ludskej existencii““ (Florenskij 1990, 347). Objavit’ prvok večnosti v časnej existencii znamená nájst’ spojenie s Pravdou. Preto je človek schopný len cez symbolické poznanie nazerat na Pravdu a následne čerpat $\mathrm{z}$ tohto životodárneho kontaktu, ktorý dáva existencii zmysel.

Symbol je teda najvlastnejším dotykom s tým, čo stojí pôvodne akoby mimo nášho racionálneho vedomia, pričom zabezpečuje kontakt so živou skutočnostou. Tak špecifický kontakt si však bude vyžadovat' odvahu vystúpit’ z obmedzení ludskej subjektivity, vykročit’ na cestu aktívneho a uvedomelého prehĺbenia interpersonálnych vztahov. V tom je jadro Florenského personalizmu a v tom vidí Florenskij nádej pre kultúru a spoločnost' nielen svojej doby. 


\section{REFERENCES}

\section{Primary sources}

Beliy, Andrej. 1994. Символизм как мировоззренъие [Symbolism as aesthetic]. Moscow. Florenski, Pavol A. 1992. Детям моим [My children]. Moscow.

Florenski, Pavol A. 1990. У водоразделов мысли II [On Watershed of Mind II]. Moscow. Florenski, Pavol A. 1992. У водоразделов мысли III [On Watershed of Mind III]. Moscow. Florenski, Pavol A. 1996. Избранные труды по искусству [Selected papers from Art]. Moscow. Choružiy, Sergej S. 1994. После переыва [After this]. Sankt-Petersburg.

Ivanov, Viacheslav I. 1998. Лик и личины России [Mask and unmasks of Russia]. Moscow.

\section{Secondary sources}

Feber, Jaromír. 2017. Reflexe člověka v ruské filozofii. In Feber, Jaromír - Rusnák, Peter (eds.). Reflexia človeka v slovanskom filozofickom prostredí. Trnava, 95-106.

Hamada, Milan. 2011. Slovanstvo a svet budúcnosti v kontexte romantického slavianofilstva a mesianizmu. In Hrehová, Helena - Rusnák, Peter (eds.). Fenomén krásy v reflexii súčasného slovanského myslenia. Trnava, 19-26.

Obolevitch, Teresa. 2014. La Philosophie Religieuse Russe. Paris.

Pašteková, Soňa. 2012. „Strieborný vek“ ruskej literatúry. Pojmy a interpretácie. In World Literature Studies 4/1, s. 81-88.

Pružinec, Tomáš. 2017. Človek a technika. Náčrt problematiky na pozadí myšlienok Nikolaja Alexandroviča Berd’ajeva. In Feber, Jaromír - Rusnák, Peter (eds.). Reflexia človeka v slovanskom filozofickom prostredí. Trnava, 134-144.

Rusnák, Peter. 2015. The Significance of Religion in Heidegger's Thinking and the Cult in Florensky's. In Rojek, Pawel - Obolevitch, Teresa (eds.). Faith and Reason in Russian Thought. Kraków, 161-172.

Rusnák, Peter. 2016. Noetický symbolizmus a konkrétna metafyzika ako výzvy pre súčasné ruské myslenie. In Hrehová, Helena - Feber, Jaromír - Rusnák, Peter (eds.). Sociálno-etické motívy v súčasnej ruskej filozofii. Trnava, 194-151.

Rusnák, Peter. 2017. Selected Themes between West European Philosophical Thinking and P. A. Florensky. In Space and Time 27/1, 96-105.

Vadíková, Katarína. 2011. Problematika svedomia v kontexte dialogického personalizmu. Trnava.

SUMMARY: SPECIFIC FEATURES OF FLORENSKI'S PERSONALISM (THE CONCEPT OF THE SYMBOL AS A UNIQUE RELATIONSHIP OF LANGUAGE AND PERSONAL BEING IN SLAVIC THOUGHT). The philosophy of Paul A. Florenski examines the definition of truth and, at the same time, it examines the thought of man and God. Florenski understands truth as an existential relationship that has a deeper meaning and which exists in a dialogue with a personal God. According to Florenski, technical thought is determined by the world of objects. The real knowledge, however, is not the knowledge of the material world and attempts at the absolutisation of the relative result in forgetting the Truth. Human being cannot be defined in terms of reasoning. Man can only be understood by means of intuition and revelation through symbol. The issue of the theory of understanding becomes an issue of the means of the interpretation of symbols. A symbol is a result of the mutual synergetic interplay of the energies of being. Symbolic understanding is ontological: a symbol is a matter 
Peter Rusnák

of being. Replacing an ontological statement by pragmatic language suggests a functionalist understanding of man, which is simplistic and linked to the discourse of mass culture.

doc. PhDr. Peter Rusnák, PhD.

University of Trnava

Faculty of Arts and Philosophy

Institute of Ethics and Moral Philosophy

Hornopotočná 23

91843 Trnava

Slovakia

peter.rusnak@truni.sk 